\title{
PRE-BOMB SURFACE WATER RADIOCARBON OF THE GULF OF MEXICO AND CARIBBEAN AS RECORDED IN HERMATYPIC CORALS
}

\author{
Amy J Wagner ${ }^{1,2} \cdot$ Thomas P Guilderson $^{3,4} \cdot$ Niall C Slowey $^{1} \cdot$ Julia E Cole $^{5}$ \\ ABSTRACT. Radiocarbon measurements of hermatypic corals from 4 sites in the Gulf of Mexico (GOM) and Caribbean \\ Sea were made to estimate the marine ${ }^{14} \mathrm{C}$ reservoir age $(R)$ and the marine regional correction $(\Delta R)$ for this region. Coral \\ skeletal material from the Flower Garden Banks (northern GOM continental shelf), Veracruz, Mexico, and 2 reefs from the \\ Cariaco Basin, Venezuela, were analyzed. Annual and subannual samples from $1945-1955$ were milled and ${ }^{14} \mathrm{C}$ composition \\ was determined. In the Gulf of Mexico, average coral $\Delta{ }^{14} \mathrm{C}$ is $-52.6 \pm 0.7 \%$ and average $\Delta^{14} \mathrm{C}$ for the Cariaco Basin corals \\ is $-53.4 \pm 0.8 \%$. Average values for the marine reservoir age and $\Delta \mathrm{R}$ are computed with this data and compared with results \\ derived from previous measurements made in the same regions. These values are important in calibrating the ${ }^{14} \mathrm{C}$ ages of car- \\ bonate samples from the area.
}

\section{INTRODUCTION}

Due to the rapid mixing rates in the atmosphere, terrestrial organisms typically exhibit ${ }^{14} \mathrm{C} /{ }^{12} \mathrm{C}$ concentrations in equilibrium with that of the atmosphere (once corrected for mass dependent fractionation). Alternately, marine organisms generally deposit their carbonate shells close to isotopic equilibrium with the seawater in which they are living (deriving carbon from the DIC of the surrounding water). Because of the large carbon reservoir of the oceans and the rates in which carbon mixes across the ocean-atmosphere boundary and across the interface between the ocean's surface mixed layer and underlying waters, the surface mixed layer of the ocean is depleted in ${ }^{14} \mathrm{C}$ relative to the atmosphere. This causes marine organisms to exhibit an apparent ${ }^{14} \mathrm{C}$ age greater than their contemporaneous terrestrial counterparts. It is therefore necessary to apply a correction in order to compare marine and terrestrial samples. This correction is termed the marine reservoir age, R, (Stuiver et al. 1986 ) and is the difference in years between the measured ${ }^{14} \mathrm{C}$ age of a marine organism's carbonate shell and the atmospheric ${ }^{14} \mathrm{C}$ age at the time as reported in the terrestrial calibration curve, IntCal04 (Reimer et al. 2004). Additionally, a regional correction designated as $\Delta \mathrm{R}$ (Stuiver and Braziunas 1993) is needed to adjust for the difference between the regional reservoir age and the nominal average global marine reservoir age for surface ocean waters based on a one-dimensional marine box model (Oeschger et al. 1975). The marine model is forced with a prescribed atmospheric $\Delta^{14} \mathrm{C}$ and $\mathrm{pCO}^{2}$ based on an average air-sea exchange coefficient, which causes regional excursions from the global average. Due to temporally and spatially varying oceanographic processes that can influence surface water ${ }^{14} \mathrm{C}$, the regional reservoir age can differ greatly from the global marine average. Therefore, it is important to know the regional correction $(\Delta \mathrm{R})$ when calibrating marine samples with the internationally ratified marine calibration curve, Marine04 (Hughen et al. 2004a). At present, only a few studies have computed the reservoir age and $\Delta \mathrm{R}$ in the Caribbean, and there have been no studies within the Gulf of Mexico (Figure 1). Here, we present ${ }^{14} \mathrm{C}$ reservoir age and $\Delta \mathrm{R}$ corrections based on marine carbonates from 4 locations in the Caribbean and Gulf of Mexico.

\section{GENERAL OCEANOGRAPHY}

The 2 regions of focus in this study are the Gulf of Mexico and Caribbean Sea (Figure 1). The main surface currents in the Caribbean region are the Caribbean Current, Yucatan Current, Loop Current

\footnotetext{
${ }^{1}$ Department of Oceanography, Texas A\&M University, College Station, Texas 77843, USA.

${ }^{2}$ Now at: Cooperative Institute for Research in Environmental Sciences, University of Colorado at Boulder and NOAA Paleoclimatology Branch, Boulder, Colorado 80305, USA. Corresponding author. Email: amy.wagner@noaa.gov.

${ }^{3}$ Center for Accelerator Mass Spectrometry, Lawrence Livermore National Laboratory, Livermore, California 94551, USA.

${ }^{4}$ Department of Ocean Sciences, University of California - Santa Cruz, Santa Cruz, California 95064, USA.

${ }^{5}$ Department of Geosciences, University of Arizona, Tucson, Arizona 85721, USA.
} 
(Gulf of Mexico), and the Florida Current (Centurioni and Niiler 2003). Water entering the Caribbean originates from both the North and South Atlantic oceans (Wilson and Johns 1997). Water flows into the Caribbean Sea in the southeast and flows westward as the Caribbean Current. Surface current velocities, as high as $70 \mathrm{~cm} \mathrm{~s}^{-1}$, are highest along the coast of Venezuela and the Netherland Antilles. The Caribbean Current then turns northwest past the Colombian Basin $\left(80^{\circ} \mathrm{W}, 12^{\circ} \mathrm{N}\right)$. It is channeled through a trough southwest of Jamaica and then through the Yucatan Channel as the Yucatan Current (Fratantoni 2001).

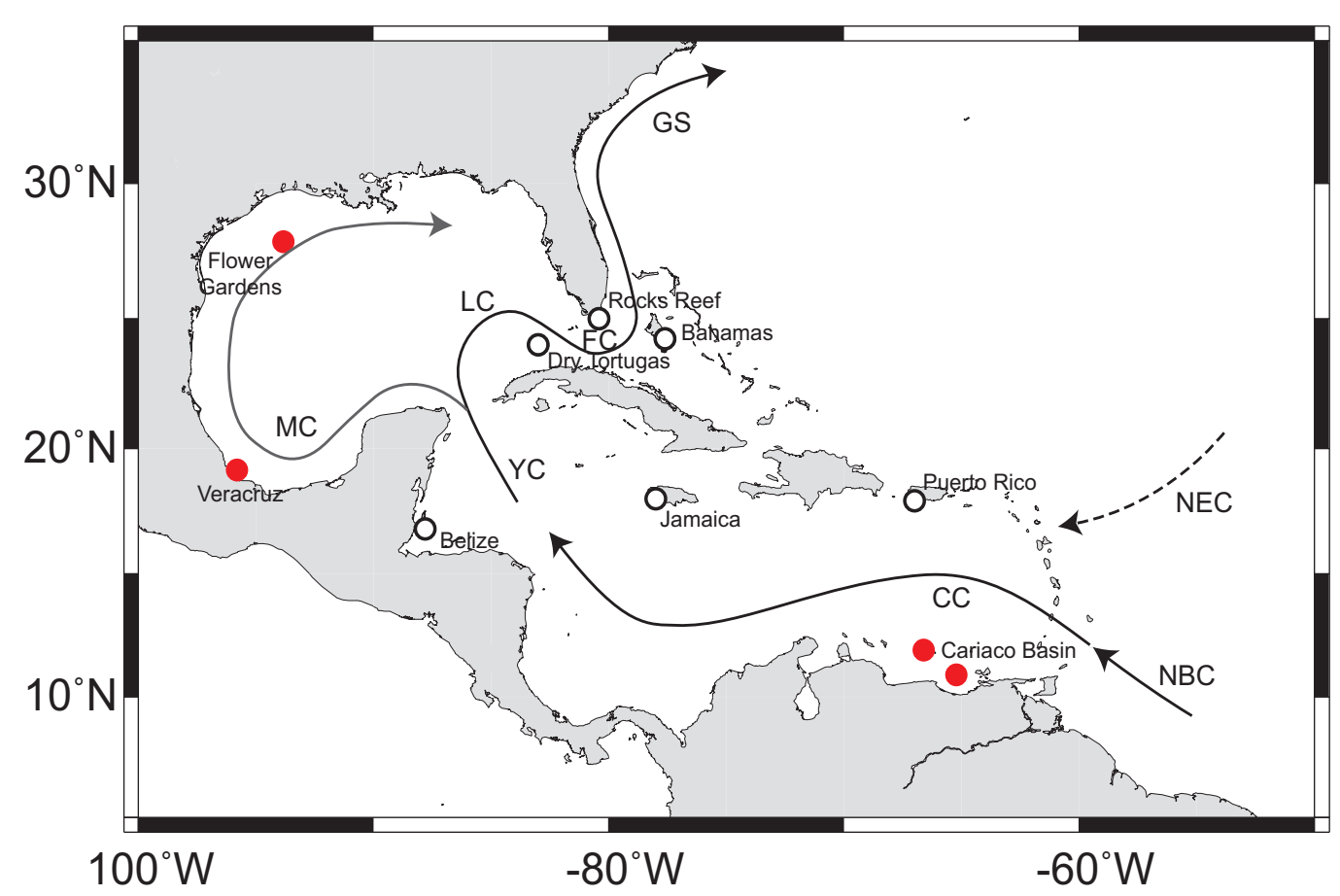

Figure 1 Existing ${ }^{14} \mathrm{C}$ sites in the Caribbean and Gulf of Mexico shown as open circles. New sites from this study indicated by closed circles. Some major surface currents are labeled (CC - Caribbean Current, FC - Florida Current, GS - Gulf Stream, LC - Loop Current, MC - Mexican Current, NBC - North Brazil Current, NEC - North Equatorial Current, and YC - Yucatan Current).

Once in the Gulf of Mexico, the Yucatan Current initially follows the continental shelf break from $21^{\circ} \mathrm{N}$ to $24.5^{\circ} \mathrm{N}$ and then changes direction to a northwesterly direction around $23.5^{\circ} \mathrm{N}, 87^{\circ} \mathrm{W}$ (Molinari and Cochrane 1972). There is a clockwise flow that extends northward into the Gulf of Mexico and joins the Yucatan Current and the Florida Current, which is known as the Loop Current. The position of the Loop Current is variable and can intrude into the Gulf of Mexico as an intense clockwise flow as far north as $29.1^{\circ} \mathrm{N}$ or it can flow in an almost direct path to the Florida Current (Molinari et al. 1977; Sturges and Evans 1983). The Yucatan and Florida currents have been shown to be within $10 \%$ of each other's volume at any given time (Molinari and Morrison 1988). Therefore, variabilities in the Loop and Yucatan currents are expected to have a strong impact on the Florida Current. In addition to the Loop Current, Sturges and Blaha (1976) have suggested a western boundary current in the far western Gulf of Mexico that stems from the Yucatan Current as it enters the Gulf of Mexico.

Considering the rate (24-30 Sv) at which the surface water is entering the Gulf of Mexico through the Yucatan Channel and leaving through the Florida Straits, the residence time within the mixed 
layer is relatively short (on the order of 2 to 3 months). The corals in this study from the Gulf of Mexico are from the upper $20 \mathrm{~m}$ and are therefore typically bathed in surface water from the Caribbean Sea. This suggests that the reservoir age of carbonates from the Gulf of Mexico should be similar to that of carbonates in the Caribbean Sea.

\section{METHODS}

Coral cores were collected from live corals using diver-operated underwater hydraulic drilling equipment. All specimens are of the species Montastraea faveolata, a common Caribbean reefbuilding hermatypic coral that exhibits regular annular banding (Goreau 1959; Hudson et al. 1976; Fairbanks and Dodge 1979; Dodge and Lang 1983). Two coral cores each from the Gulf of Mexico and the Cariaco Basin were used in this study (Figure 2). The first was collected in May 1990 from the Flower Garden Banks National Marine Sanctuary $\left(93^{\circ} 50^{\prime} \mathrm{W}, 27^{\circ} 52^{\prime} \mathrm{N}\right)$ in approximately $20 \mathrm{~m}$ of water. The Flower Garden Banks are located approximately $180 \mathrm{~km}$ south of the Texas/Louisiana border on the continental shelf of the northern Gulf of Mexico. The second specimen from the Gulf of Mexico is from Santiaguillo Reef $\left(95^{\circ} 48.5^{\prime} \mathrm{W}, 19^{\circ} 08.3^{\prime} \mathrm{N}\right)$, which is located about $20 \mathrm{~km}$ off the coast of Veracruz, Mexico, in the western Gulf of Mexico. The coral grew in $\sim 6 \mathrm{~m}$ of water and was drilled in 1991. The 2 coral cores from the Cariaco Basin used in this study are from Boca de Medio Island $\left(66^{\circ} 36^{\prime} \mathrm{W}, 11^{\circ} 55^{\prime} \mathrm{N}\right)$ and Isla Tortuga $\left(65^{\circ} 21^{\prime} \mathrm{W}, 10^{\circ} 53^{\prime} \mathrm{N}\right)$. Boca de Medio is located in the Los Roques archipelago, outside of the Cariaco Basin proper. The sample was drilled in July 1998 in water depth of $\sim 2 \mathrm{~m}$. Isla Tortuga is located at the northern margin of the Cariaco Basin. The coral core was collected from the southern coast of the island in March 1996 in water depth of $\sim 2 \mathrm{~m}$.

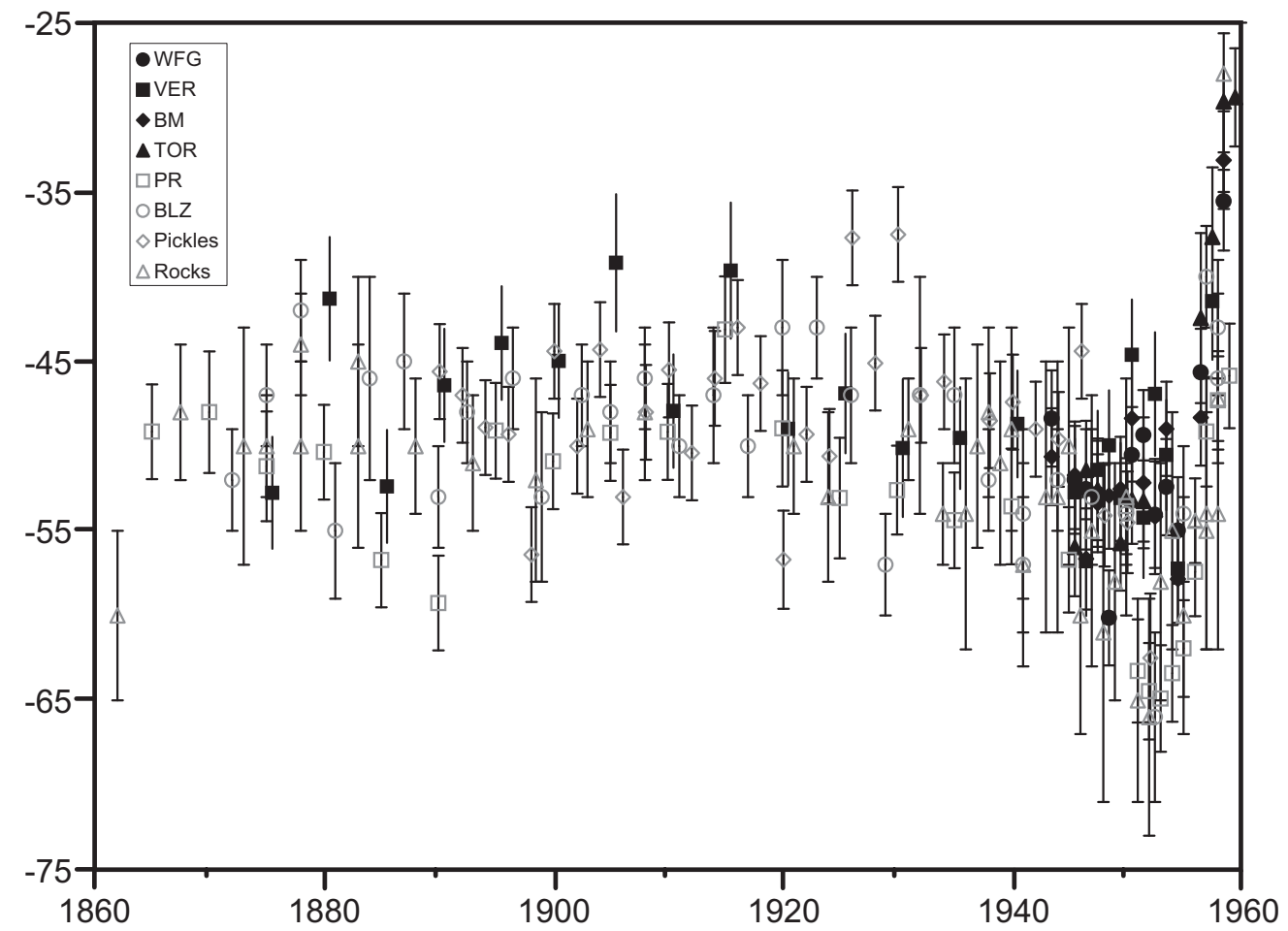

Figure 2 Caribbean and Gulf of Mexico coral $\Delta^{14} \mathrm{C}$ records. New data are shown as solid black symbols (WFG - West Flower Gardens, Gulf of Mexico; VER - Veracruz, Mexico; BM - Boca de Medio, Cariaco Basin; TOR - Isla Tortugas, Cariaco Basin). Data previously published are shown as open gray symbols (PR - Puerto Rico; BLZ - Gulf of Honduras, Belize; Pickles - Pickles Reef, Florida; Rocks - Rocks Reef, Florida). Error bars indicate 1 standard deviation. 
The cores were cut into $\sim 10-\mathrm{mm}$ slabs, cleaned, and air-dried. Coral slabs were X-rayed to determine the high- and low-density band couplet. Ages were then assigned using the density bands and counting back from the top of the core. Based on published literature, we assumed the high-density bands were formed during the Northern Hemisphere summer season (e.g. Hudson et al. 1976). Samples were micromilled from the respective slabs to obtain calcium carbonate from the corals for ${ }^{14} \mathrm{C}$ analysis. Annual samples for years 1945-1954 were chosen for analysis in this study because of the years of overlap between the individual coral cores prior to atmospheric nuclear weapons testing. ${ }^{14} \mathrm{C}$ measurements were made at the Center for Accelerator Mass Spectrometry (CAMS) at the Lawrence Livermore National Laboratory (Davis et al. 1990). Annual samples of $\sim 10 \mathrm{mg}$ were placed in individual vacutainers, evacuated, heated, and acidified with orthophosphoric acid at $90{ }^{\circ} \mathrm{C}$. The resultant $\mathrm{CO}_{2}$ was then converted to graphite in the presence of an iron catalyst (Vogel et al. 1987). ${ }^{14} \mathrm{C}$ results are reported as age-corrected $\Delta^{14} \mathrm{C}(\%)$ as defined by Stuiver and Polach (1977) and include a background and $\delta^{13} \mathrm{C}$ correction. Reproducibility of results is better than $\pm 3.5 \%$ o $(1 \sigma)$ based on an in-house coral process standard.

\section{RESULTS}

Individual analytical results are presented in Table 1 . We do not make any attempt to correct for the Suess effect as there is no noticeable trend in our samples. During the years that the records overlap (1945-1954) and prior to the atmospheric nuclear weapons testing, all 4 records show similar $\Delta^{14} \mathrm{C}$ values (Table 2). The mean Flower Garden Banks $\Delta^{14} \mathrm{C}$ is $-53.2 \pm 1.0 \%(n=9)$; the Veracruz, Mexico, average $\Delta^{14} \mathrm{C}$ is $-51.9 \pm 1.1 \%$ o $(n=10)$; the average Boca de Medio $\Delta{ }^{14} \mathrm{C}$ is $-53.2 \pm 1.0 \%$ $(n=10)$; and the Isla Tortuga mean $\Delta^{14} \mathrm{C}$ is $-53.9 \pm 1.5 \%$ o $(n=3)$. The 2 Gulf of Mexico records combined have an average $\Delta^{14} \mathrm{C}$ of $-52.6 \pm 0.7 \%(n=19)$ and the 2 Cariaco Basin records have an average $\Delta^{14} \mathrm{C}$ of $-53.4 \pm 0.8 \%$ o $(n=13)$.

The $\Delta^{14} \mathrm{C}$ of the Northern Hemisphere atmosphere in 1950 as recorded in tree rings is $-24.5 \pm 1.1 \%$ o (Reimer et al. 2004) and the $\Delta^{14} \mathrm{C}$ of the global ocean as derived from the Marine 04 model is $-56.7 \pm$ $2.8 \%$. These results yield average reservoir ages of $235 \pm 11 \mathrm{yr}(\Delta \mathrm{R}$ of $-36 \pm 25 \mathrm{yr}$ ) and $242 \pm 12 \mathrm{yr}$ $(\Delta \mathrm{R}$ of $-28 \pm 25 \mathrm{yr}$ ) in the Gulf of Mexico and Cariaco Basin, respectively.

Because of the surface circulation of the region (discussed above) it is reasonable to consider the Caribbean and Gulf of Mexico data together to obtain values representative of the entire region. The average $\Delta^{14} \mathrm{C}$ of all 4 records is $-52.9 \pm 0.5 \%$ o $(n=32)$. These results yield an average reservoir age of $238 \pm 10 \mathrm{yr}$ and a $\Delta \mathrm{R}$ of $-32 \pm 25 \mathrm{yr}$.

The sample from Veracruz, Mexico, extended before the time of significant industrialization and therefore lacks the Suess effect in its earliest years. The average $\Delta^{14} \mathrm{C}$ for the pre-industrial time period $1875-1895$ is $-47.6 \pm 1.5 \%$ o $(n=5)$, which yields a reservoir age of $354 \pm 15 \mathrm{yr}$ and a $\Delta \mathrm{R}$ of $-13 \pm 27 \mathrm{yr}$.

\section{DISCUSSION}

Coral ${ }^{14} \mathrm{C}$ pre-bomb values are nearly indistinguishable among all sites. The average Gulf of Mexico reservoir age is $235 \pm 11 \mathrm{yr}$ and a $\Delta \mathrm{R}$ of $-35 \pm 25 \mathrm{yr}$. This compares well to an average of $280 \pm$ $44 \mathrm{yr}$ and $\Delta \mathrm{R}$ of $10 \pm 49 \mathrm{yr}$ for all previously published data from the region (Table 3 ). The average reservoir age and $\Delta \mathrm{R}$ for the Cariaco Basin results is $242 \pm 12 \mathrm{yr}$ and $-28 \pm 25 \mathrm{yr}$, respectively. Surface water $\Delta^{14} \mathrm{C}$ in the Gulf of Mexico and Cariaco Basin are so similar due to the rapid transport between the basins with relatively little modification of the water masses. 
Table 1 Raw data from this study.

\begin{tabular}{|c|c|c|c|c|}
\hline Site & Year & $\begin{array}{l}{ }^{14} \mathrm{C} \text { age } \\
\text { (conventional) }\end{array}$ & $\begin{array}{l}\text { Fraction modern } \\
\text { (absolute) }\end{array}$ & $\begin{array}{l}\Delta^{14} \mathrm{C}(\%) \\
\text { (age-corrected) }\end{array}$ \\
\hline \multicolumn{5}{|c|}{ West Flower Gardens } \\
\hline & 1954.5 & $450 \pm 30$ & $0.9450 \pm 0.0031$ & $-55.0 \pm 3.1$ \\
\hline & 1953.5 & $430 \pm 25$ & $0.9476 \pm 0.0028$ & $-52.4 \pm 2.8$ \\
\hline & 1952.5 & $445 \pm 30$ & $0.9460 \pm 0.0031$ & $-54.0 \pm 3.1$ \\
\hline & 1951.5 & $405 \pm 25$ & $0.9506 \pm 0.0027$ & $-49.4 \pm 2.7$ \\
\hline & 1950.5 & $415 \pm 25$ & $0.9495 \pm 0.0028$ & $-50.5 \pm 2.8$ \\
\hline & 1948.5 & $500 \pm 25$ & $0.9399 \pm 0.0028$ & $-60.1 \pm 2.8$ \\
\hline & 1947.5 & $440 \pm 30$ & $0.9472 \pm 0.0031$ & $-52.8 \pm 3.1$ \\
\hline & 1946.5 & $435 \pm 35$ & $0.9475 \pm 0.0036$ & $-52.5 \pm 3.6$ \\
\hline & 1945.5 & $435 \pm 30$ & $0.9480 \pm 0.0032$ & $-52.0 \pm 3.2$ \\
\hline \multicolumn{5}{|c|}{ Veracruz, Mexico } \\
\hline & 1954.5 & $470 \pm 30$ & $0.9428 \pm 0.0032$ & $-57.2 \pm 3.2$ \\
\hline & 1953.5 & $415 \pm 30$ & $0.9495 \pm 0.0033$ & $-50.5 \pm 3.3$ \\
\hline & 1952.5 & $385 \pm 35$ & $0.9531 \pm 0.0036$ & $-46.9 \pm 3.6$ \\
\hline & 1951.5 & $445 \pm 35$ & $0.9458 \pm 0.0036$ & $-54.2 \pm 3.6$ \\
\hline & 1950.5 & $365 \pm 30$ & $0.9554 \pm 0.0033$ & $-44.6 \pm 3.3$ \\
\hline & 1949.5 & $440 \pm 30$ & $0.9469 \pm 0.0032$ & $-53.1 \pm 3.2$ \\
\hline & 1948.5 & $415 \pm 30$ & $0.9500 \pm 0.0033$ & $-50.0 \pm 3.3$ \\
\hline & 1947.5 & $425 \pm 30$ & $0.9486 \pm 0.0035$ & $-51.4 \pm 3.5$ \\
\hline & 1946.5 & $475 \pm 30$ & $0.9432 \pm 0.0032$ & $-56.8 \pm 3.2$ \\
\hline & 1945.5 & $440 \pm 30$ & $0.9473 \pm 0.0032$ & $-52.7 \pm 3.2$ \\
\hline & 1895.5 & $415 \pm 30$ & $0.9561 \pm 0.0034$ & $-43.9 \pm 3.4$ \\
\hline & 1890.5 & $440 \pm 30$ & $0.9536 \pm 0.0033$ & $-46.4 \pm 3.3$ \\
\hline & 1885.5 & $495 \pm 30$ & $0.9476 \pm 0.0033$ & $-52.4 \pm 3.3$ \\
\hline & 1880.5 & $405 \pm 35$ & $0.9587 \pm 0.0036$ & $-41.3 \pm 3.6$ \\
\hline & 1875.5 & $510 \pm 30$ & $0.9472 \pm 0.0033$ & $-52.8 \pm 3.3$ \\
\hline \multicolumn{5}{|c|}{ Boca de Medio } \\
\hline & 1954.5 & $475 \pm 25$ & $0.9421 \pm 0.0026$ & $-57.9 \pm 2.6$ \\
\hline & 1953.5 & $400 \pm 25$ & $0.9510 \pm 0.0028$ & $-49.0 \pm 2.8$ \\
\hline & 1952.5 & $445 \pm 30$ & $0.9458 \pm 0.0034$ & $-54.2 \pm 3.4$ \\
\hline & 1951.5 & $430 \pm 35$ & $0.9478 \pm 0.0039$ & $-52.2 \pm 3.9$ \\
\hline & 1950.5 & $400 \pm 35$ & $0.9516 \pm 0.0037$ & $-48.4 \pm 3.7$ \\
\hline & 1949.5 & $435 \pm 30$ & $0.9475 \pm 0.0031$ & $-52.5 \pm 3.1$ \\
\hline & 1948.5 & $440 \pm 30$ & $0.9471 \pm 0.0031$ & $-52.9 \pm 3.1$ \\
\hline & 1947.5 & $445 \pm 25$ & $0.9466 \pm 0.0029$ & $-53.4 \pm 2.9$ \\
\hline & 1946.5 & $470 \pm 30$ & $0.9433 \pm 0.0030$ & $-56.7 \pm 3.0$ \\
\hline & 1945.5 & $430 \pm 30$ & $0.9483 \pm 0.0032$ & $-51.7 \pm 3.2$ \\
\hline \multicolumn{5}{|c|}{ Isla Tortugas } \\
\hline & 1951.5 & $440 \pm 25$ & $0.9468 \pm 0.0024$ & $-53.2 \pm 2.4$ \\
\hline & 1950.5 & $440 \pm 25$ & $0.9468 \pm 0.0026$ & $-53.2 \pm 2.6$ \\
\hline & 1949.5 & $460 \pm 25$ & $0.9443 \pm 0.0028$ & $-55.7 \pm 2.8$ \\
\hline & 1947.5 & $435 \pm 30$ & $0.9475 \pm 0.0030$ & $-52.5 \pm 3.0$ \\
\hline & 1946.5 & $425 \pm 25$ & $0.9486 \pm 0.0029$ & $-51.4 \pm 2.9$ \\
\hline & 1945.5 & $465 \pm 25$ & $0.9440 \pm 0.0029$ & $-56.0 \pm 2.9$ \\
\hline
\end{tabular}


Table 2 Age-corrected $\Delta^{14} \mathrm{C}$, conventional ${ }^{14} \mathrm{C}$ age of sample, computed reservoir age, and computed $\Delta \mathrm{R}$ for coral samples used in this study. $\Delta{ }^{14} \mathrm{C}$ and ${ }^{14} \mathrm{C}$ ages are calculated using weighted average of individual data points. Variance is weighted mean measurement error.

\begin{tabular}{|c|c|c|c|c|c|}
\hline Site & $\begin{array}{l}\text { Midpoint } \\
\text { (year) }\end{array}$ & $\begin{array}{l}\Delta^{14} \mathrm{C}(\%) \\
\text { (age-corrected) }\end{array}$ & $\begin{array}{l}{ }^{14} \mathrm{C} \text { age } \\
\text { (conventional) }\end{array}$ & $\begin{array}{l}\text { Reservoir age } \\
(\mathrm{yr})\end{array}$ & $\begin{array}{l}\Delta \mathrm{R} \\
(\mathrm{yr})\end{array}$ \\
\hline Flower Garde & $50(n=9)$ & $-53.2 \pm 1.0$ & $439=$ & 240 & $-30 \pm 26$ \\
\hline Veracruz, Mexico & 1950 & -51.9 & 428 & & $-41 \pm 26$ \\
\hline Gulf of Mexico Avg & $1950(n=19)$ & $-52.6=$ & 434 & 235 & $-36 \pm 25$ \\
\hline Boca & $1950(r$ & -53 . & 438 & 239 & $-31 \pm 26$ \\
\hline Isla $\mathrm{T}$ & $1950(n$ & -53.9 & 447 & & $-22 \pm 28$ \\
\hline Caribbean Avg & $1950(n=13)$ & $-53.4 \pm 0.8$ & $441 \pm 8$ & $242 \pm 12$ & $-28 \pm 25$ \\
\hline Veracruz, Mexico & $1885(n=5)$ & $-47.6 \pm 1.5$ & $456 \pm 14$ & $354 \pm 15$ & $-13 \pm 27$ \\
\hline
\end{tabular}

Table 3 Previously published $\Delta{ }^{14} \mathrm{C}$ data from the Caribbean Sea and Gulf of Mexico.

\begin{tabular}{lllrll}
\hline & \multicolumn{2}{l}{ Reservoir } & & \\
Site & Year & age & \multicolumn{1}{c}{$\Delta \mathrm{R}$} & Reference & Material \\
\hline Bahamas & 1950 & $229 \pm 43$ & $-40 \pm 42$ & Broecker and Olson 1961 & Gastropod \\
Bahamas & 1885 & $423 \pm 59$ & $56 \pm 59$ & Broecker and Olson 1961 & Gastropod \\
The Rocks, FL Keys & 1950 & $281 \pm 21$ & $11 \pm 31$ & Druffel 1980 & Coral \\
The Rocks, FL Keys & 1850 & $405 \pm 18$ & $33 \pm 16$ & Druffel and Linick 1978; & Coral \\
& & & & Druffel 1982 & \\
Tortugas, FL & 1884 & $482 \pm 52$ & $114 \pm 51$ & Lighty et al. 1982 & Coral \\
Golden Cay, Bahamas & 1912 & $493 \pm 66$ & $146 \pm 66$ & Lighty et al. 1982 & Coral \\
Gulf of Honduras, Belize & 1950 & $259 \pm 20$ & $-11 \pm 30$ & Druffel 1980 & Coral \\
Jamaica & 1884 & $323 \pm 42$ & $-44 \pm 41$ & Broecker and Olson 1961 & Gastropod \\
Jamaica & 1930 & $273 \pm 43$ & $-30 \pm 42$ & Broecker and Olson 1961 & Gastropod \\
La Parguera, Puerto Rico & 1950 & $306 \pm 14$ & $36 \pm 26$ & Kilbourne et al. 2007 & Coral \\
La Parguera, Puerto Rico & 1885 & $402 \pm 13$ & $35 \pm 26$ & Kilbourne et al. 2007 & Coral \\
Cariaco Basin, Venezuela & 1935 & $336 \pm 61$ & $33 \pm 60$ & Hughen et al. 2004b & Foraminifera \\
Cariaco Basin, Venezuela & 1910 & $361 \pm 50$ & $12 \pm 50$ & Hughen et al. 2004b & Foraminifera \\
Isla Tortuga, Venezuela & 1941 & $264 \pm 41$ & $-22 \pm 40$ & Guilderson et al. 2005 & Coral \\
Isla Tortuga, Venezuela & 1906 & $290 \pm 41$ & $-70 \pm 40$ & Guilderson et al. 2005 & Coral \\
Boca de Medio, Venezuela & 1945 & $256 \pm 42$ & $-18 \pm 41$ & Guilderson et al. 2005 & Coral \\
Los Testigos, Venezuela & 1940 & $285 \pm 43$ & $-1 \pm 42$ & Guilderson et al. 2005 & Coral \\
\hline
\end{tabular}

The small $\Delta \mathrm{R}$ values for the Caribbean and Gulf of Mexico region imply good agreement with the one-dimensional marine model and the atmospheric curve used to derive the Marine04 curve and estimate the global marine ${ }^{14} \mathrm{C}$ age. This implies common source waters and short residence times and indicates the rate of air-sea exchange of $\mathrm{CO}_{2}$ in this region is close to the global average. Therefore, for the pre-bomb period the global marine model can be used to provide a reasonable estimate of the ${ }^{14} \mathrm{C}$ age of marine samples for the Caribbean and Gulf of Mexico for modern times (i.e. when boundary conditions in the area are as they are today).

At times in the past when different climatic/oceanographic regimes existed, one cannot make this same assumption. For example, a change in the relative proportions of surface water from the North and South Atlantic would have an impact on the reservoir and $\Delta \mathrm{R}$ ages of the region. The $\Delta \mathrm{R}$ calculated from a coral off southern Puerto Rico is $36 \pm 26$ yr (Kilbourne et al. 2007) compared to $-32 \pm$ 
$25 \mathrm{yr}$ for the Caribbean. The difference between the values is due to the difference in source water to the areas (Northern Atlantic via the North Equatorial Current versus equatorial waters via the Northern Boundary Current).

\section{CONCLUSIONS}

We present estimates of the surface water $\Delta^{14} \mathrm{C}$ concentration in the Caribbean Sea and Gulf of Mexico. The average ${ }^{14} \mathrm{C}$ for the region is $-52.9 \pm 0.5 \%$. This yields an average reservoir age of $238 \pm$ $10 \mathrm{yr}$ and $\Delta \mathrm{R}$ of $-32 \pm 25 \mathrm{yr}$. These values are close to previously published reservoir ages and $\Delta \mathrm{R}$ ages for the Caribbean. The relatively small $\Delta \mathrm{R}$ ages compared to the marine 1-D model suggest the Marine 04 curve is a reasonable approximation for this region for the modern oceanographic regime. This may not be the case during the past when significantly different oceanographic and climatic regimes existed. The smaller reservoir age compared to the marine model is consistent with short residence times in the Caribbean and Gulf of Mexico and high rates of air-sea exchange of $\mathrm{CO}_{2}$. There is little to no Suess effect apparent in the Gulf of Mexico $\Delta^{14} \mathrm{C}$ values, which implies a relatively small amount of ${ }^{14} \mathrm{C}$-depleted atmospheric $\mathrm{CO}_{2}$ being mixed into the surface waters.

\section{ACKNOWLEDGMENTS}

The authors would like to acknowledge the Department of Energy Global Change Education Program for funding A Wagner and Texas Sea Grant for support under Grant $\# 02-404333 .{ }^{14} \mathrm{C}$ analyses were performed under the auspices of the US Department of Energy by the University of California Lawrence Livermore National Laboratory (contract W-7405-Eng-48). We thank K Deslarzes for providing the Flower Garden Banks and Veracruz coral cores for analysis and P Zermeño and D Kurdyla for their assistance with preparation of graphite targets. We also thank J McGeehin and $\mathrm{T}$ Jull for their thoughtful reviews and comments on an earlier version of this manuscript. Data will be digitally archived at NOAA's World Data Center for Paleoclimatology (Boulder, Colorado, USA) and will be submitted to the CALIB Marine Reservoir Database (Queen's University, Belfast).

\section{REFERENCES}

Broecker WS, Olson EA. 1961. Lamont radiocarbon measurements VIII. Radiocarbon 3:176-204.

Centurioni LR, Niiler PP. 2003. On the surface currents of the Caribbean Sea. Geophysical Research Letters 30(6): doi:10.1029/2002GL016231.

Davis JC, Proctor ID, Southon JR, Caffee MW, Heikkinen DW, Roberts ML, Moore TL, Turteltaub KW, Nelson DE, Loyd DH, Vogel JS. 1990. LLNL/UC AMS facility and research program. Nuclear Instruments and Methods in Physics Research B 52(3-4): 269-72.

Dodge RE, Lang JC. 1983. Environmental correlates of hermatypic coral (Montastrea annularis) growth on the East Flower Gardens Bank, northwest Gulf of Mexico. Limnology and Oceanography 28(2):228-40.

Druffel EM. 1980. Radiocarbon in annual coral rings of Belize and Florida. Radiocarbon 22(2):363-71.

Druffel EM. 1982. Banded corals: changes in oceanic carbon-14 during the Little Ice Age. Science 218(4567):13-9.

Druffel EM, Linick TW. 1978. Radiocarbon in annual coral rings of Florida. Geophysical Research Letters 5(11):913-6.
Fairbanks RG, Dodge RE. 1979. Annual periodicity of the ${ }^{18} \mathrm{O} /{ }^{16} \mathrm{O}$ and ${ }^{13} \mathrm{C} /{ }^{12} \mathrm{C}$ ratios in the coral Montastrea annularis. Geochimica et Cosmochimica Acta 43(7): 1009-20.

Fratantoni DM. 2001. North Atlantic surface circulation during the 1990's observed with satellite-tracked drifters. Journal of Geophysical Research 106(C10): 22,067-93.

Goreau TF. 1959. The ecology of Jamaican coral reefs. I. Species composition and zonation. Ecology 40(1):6790.

Guilderson TP, Cole JE, Southon J. 2005. Pre-bomb $\Delta^{14} \mathrm{C}$ variability and the Suess effect in Cariaco Basin surface waters as recorded in hermatypic corals. Radiocarbon 47(1):57-65.

Hudson JH, Shinn EA, Halley RB, Lidz B. 1976. Sclerochronology: a tool for interpreting past environments. Geology 4(6):361-4.

Hughen KA, Baillie M, Bard E, Beck JW, Bertrand CJH, Blackwell PG, Buck CE, Burr GS, Cutler KB, Damon PE, Edwards RL, Fairbanks RG, Friedrich M, Guilderson TP, Kromer B, McCormac G, Manning S, Bronk Ramsey C, Reimer PJ, Reimer RW, Remmele S, Sou- 
thon JR, Stuiver M, Talamo S, Taylor FW, van der Plicht J, Weyhenmeyer C. 2004a. Marine04 marine radiocarbon age calibration, 0-26 cal kyr BP. Radiocarbon 46(3):1059-86.

Hughen KA, Southon JR, Bertrand CJH, Frantz B, Zermeño P. 2004b. Cariaco Basin calibration update: revisions to calendar and ${ }^{14} \mathrm{C}$ chronologies for core PL07-58PC. Radiocarbon 46(3):1161-87.

Kilbourne KH, Quinn TM, Guilderson TP, Webb RS, Taylor FW. 2007. Decadal- to interannual-scale source water variations in the Caribbean Sea recorded by $\mathrm{Pu}$ erto Rican coral radiocarbon. Climate Dynamics 29(1):51-62.

Lighty RG, Macintyre IG, Stuckenrath R. 1982. Acropora Palmata reef framework: a reliable indicator of sea level in the western atlantic for the past 10,000 years. Coral Reefs 1(2):125-30.

Molinari RL, Cochrane JD. 1972. The effect of topography on the Yucatan Current. In: Capurro LRA, Reid RO, editors. Contributions on the Physical Oceanography of the Gulf of Mexico. Houston: Gulf Publishing Company. p 149-55.

Molinari RL, Morrison J. 1988. The separation of the Yucatan Current from the Campeche Bank and the intrusion of the Loop Current into the Gulf of Mexico. Journal of Geophysical Research 93(C9):10,645-54.

Molinari RL, Baig S, Behringer DW, Maul GA, Legeckis R. 1977. Winter intrusions of the Loop Current. Science 198(4316):505-7.

Oeschger H, Siegenthaler U, Schotterer U, Gugelman A. 1975. A box diffusion model to study the carbon diox- ide exchange in nature. Tellus 27:168-92.

Reimer PJ, Baillie MGL, Bard E, Bayliss A, Beck JW, Bertrand CJH, Blackwell PG, Buck CE, Burr GS, Cutler KB, Damon PE, Edwards RL, Fairbanks RG, Friedrich M, Guilderson TP, Hogg AG, Hughen KA, Kromer B, McCormac G, Manning S, Bronk Ramsey C, Reimer RW, Remmele S, Southon JR, Stuiver M, Talamo S, Taylor FW, van der Plicht J, Weyhenmeyer CE. 2004. IntCal04 terrestrial radiocarbon age calibration, 0-26 cal kyr BP. Radiocarbon 46(3):1029-58.

Stuiver M, Braziunas TF. 1993. Modeling atmospheric ${ }^{14} \mathrm{C}$ influences and ${ }^{14} \mathrm{C}$ ages of marine samples to 10,000 BC. Radiocarbon 35(1):137-89.

Stuiver M, Polach HA. 1977. Discussion: reporting of ${ }^{14} \mathrm{C}$ data. Radiocarbon 19(3):355-63.

Stuiver M, Pearson GW, Braziunas TF. 1986. Radiocarbon age calibration of marine samples back to 9000 cal yr BP. Radiocarbon 28(2B):980-1021.

Sturges W, Blaha JP. 1976. A western boundary current in the Gulf of Mexico. Science 192(4237):367-9.

Sturges W, Evans JC. 1983. On the variability of the Loop Current in the Gulf of Mexico. Journal of Marine Research 41(4):639-53.

Vogel JS, Southon JR, Nelson DE. 1987. Catalyst and binder effects in the use of filamentous graphite for AMS. Nuclear Instruments and Methods in Physics Research B 29(1-2):50-6.

Wilson WD, Johns WE. 1997. Velocity structure and transport in the Windward Islands passages. Deep-Sea Research I 44(3):487-520. 